\title{
On the Duty of Fidelity of Husband and Wife
}

\author{
Nanyan Chen ${ }^{1}$ \\ ${ }^{1}$ Huaibei Normal University, Lieshan Town, Lieshan District, Huaibei, China \\ Correspondence: Nanyan Chen, Huaibei Normal University, Lieshan Town, Lieshan District, Huaibei, Anhui, \\ China. E-mail: 2541873342@qq.com
}

Received: January 6, 2022

doi:10.20849/ajsss.v7i1.992

Accepted: January 23, 2022

Online Published: January 26, 2022

URL: https://doi.org/10.20849/ajsss.v7i1.992

\begin{abstract}
Nowadays, due to the change of customs and order and the adverse influence of some foreign decaying economy and culture, social phenomena such as "fall in love the other woman" that undermine the harmony of the relationship between husband and wife and damage the legitimate rights and interests of one of the spouses are becoming more and more intense. For this reason, the author believes that it is very necessary for China's new Marriage Law to establish the duty of fidelity between husband and wife. By expounding the connotation and performance of the fidelity obligation of husband and wife and giving certain suggestions, this paper reveals the significance of the fidelity obligation of husband and wife, hoping to provide an opinion for its progress and development, promote China's marriage and family law to better solve social problems, and help more couples to fulfill their fidelity obligations and enjoy warm and harmonious family relations.
\end{abstract}

Keywords: serious breach, the marital fidelity obligation, solve the problem

The duty of fidelity of husband and wife is actually a norm that is beneficial to people, that is, the reasonable restrictions and constraints of the law on the married life of citizens are one of the feasible ways to guide people to obtain a perfect marriage, security and security, and a happy family. It links the development and happiness of the individual with the development and happiness of the whole society, so that people can achieve a high degree of harmony in the balance of individual interests and social interests, which is conducive to the construction of a harmonious society. In the marriage and family chapter of the Civil Code of our country, the essence of the fidelity obligation of husband and wife is mainly emphasized: 1). Husbands and wives should respect each other; 2). Husbands and wives should be faithful to each other. This obligation of mutual respect and mutual fidelity is called "the duty of conjugal fidelity".

The duty of fidelity of husband and wife mainly comes from cohabitation, that is, during the period of cohabitation between husband and wife, husband and wife should be honest and trustworthy, and carefully maintain the marital relationship. Men and women are of equal status with regard to the duty of fidelity of spouses. Whoever violates the marital fidelity obligation must bear the corresponding legal responsibility. The constraints and restrictions imposed by the duty of fidelity of husband and wife are "consistent", reflecting the spirit of "fairness, justice and openness" in the Marriage and Family Chapter of the Civil Code2. The understanding of the fidelity obligation of husband and wife can be divided into two perspectives: one is the macro perspective. From a macroscopic point of view, both husband and wife should be loyal to each other, and neither party can harm the interests of the other and cause harm to the other; The second is the microscopic perspective. Microscopically speaking, both husband and wife should maintain the specificity and absoluteness of personal chastity, and must not appear half-hearted in sexual life, and consciously resist chaotic sexual relations. These two aspects can be summed up more succinctly as both physically and spiritually faithful to each other.

So in judicial practice, how to judge that either spouse has breached the duty of fidelity of the husband and wife? China's judicial sector needs to have a sufficient basis for judgment, but it can be roughly classified into the following two types:

\section{The Internal Type of Conjugal Relationship}

In a marital relationship, if one of the spouses violates the obligation of marital fidelity and causes economic and mental losses to the other party, this kind of behavior belongs to the "internal type of conjugal relationship". For example, in recent years, many star artists such as Wenwen, Li Xiaolu and other third parties who cheated on 
each other in marriage hurt the feelings of husband and wife, seriously damaged the mental state of the other party; Ma Rong became more intense, not only the agent of wang Baoqiang, who cheated on her husband in marriage, but also transferred the marital property shared with her husband together with a third party, in addition to mentally hitting each other, it also seriously damaged each other's interests economically. These are typical cases of breaches of the marital duty of fidelity within the family.

\section{The External Type of Conjugal Relationship}

In this pattern of behaviour, it is neither the husband nor the wife who damages the relationship between husband and wife, but a third person outside the husband and wife. Due to the harm caused to either spouse due to the appearance of a third person, this kind of behavior belongs to the "external type of conjugal relationship". For example, according to a case in Shandong on the China Judgment Documents Network, the woman Zhang Hong said that she had been married to her husband Zhao Zijun for more than ten years, during which she always tried her best to be a good wife and assume the responsibility of a good wife, but she never got the satisfaction of her husband Zhao Zijun. The reason why the two parties did not establish normal conjugal feelings after marriage, the deceased mother-in-law provoked dissension from it is the key reason. The relationship between the mother-in-law and daughter-in-law is not harmonious, the two often have conflicts, the mother-in-law often says bad things about the daughter-in-law in front of her son Zhao Zijun, plus the husband and wife inevitably have friction because of some trivial matters in life, after the death of the mother-in-law, the husband Zhao Zijun also formally sued the court to dissolve the marriage relationship with his wife. Because of the above two violations of the duty of fidelity of husband and wife, it brings heavy harm to the party who has been violated by the husband and wife, but they often suffer from difficulties in seeking legal protection and help because the law has only one general and empty provision on the duty of fidelity of husband and wife. Therefore, in view of the binding force of the obligation on the husband and wife in practice, the author puts forward the following suggestions:

\section{Clarify the Content and Judgment of the Duty of Loyalty}

It is important to clarify the content of the duty of fidelity, which not only involves the determination of the relevant rights remedy, but also facilitates the legal application of the duty of fidelity. Therefore, in view of the new situation of breaching the duty of fidelity in practice this year, the author suggests that the duty of fidelity be included in Article 4 of the Marriage Law. Of course, new developments are constantly emerging. When adding new situations, we should take into account the stability of the law. Thus, we can reveal details of other breaches of the duty of fidelity on the basis of enumerating third-person participation and cohabitation. According to the above analysis, the two cases of breach of the duty of fidelity under the current law are only bigamy or cohabitation with others and cannot cover new situations that arise in practice3. In addition, the determination of the duty of fidelity should be clarified. From the existing legal provisions, we can see that there are "other circumstances that lead to the breakdown of the relationship between husband and wife". In real life, breaching the duty of fidelity does not necessarily lead to the breakdown of the couple's relationship. Therefore, the criteria for determination should be clearly defined within the scope of the content of the duty of fidelity.

\section{Broaden the Scope of Circumstances in Which the Injured Party May Request Damages for Divorce}

In terms of the subject of responsibility, China's marriage law does not stipulate the responsibility for a third party, but the duty of fidelity as a personal right is absolute, and the third party must not infringe on it at will. Where a third party outside the marital relationship harms their lawful rights and interests, it shall bear joint and several liability with the spouse of the party without fault. If we do not hold us accountable, we are suspected of condoning and violating the law with fairness and justice4.

\section{The Significance of the Duty of Fidelity of the Husband and Wife}

To bring interests or obligations into the realm of legal norms, we should first answer the question of whether the legitimization of interests or obligations has value. In jurisprudence, it is called the "purpose value of law." We plan to incorporate the duty of fidelity into the area of legal protection as a core element of spousal rights. An important reason is that the duty of fidelity between husband and wife is in line with the core values of socialism advocated by China's social development. The protection of the duty of fidelity to husband and wife is actually the state's defense and promotion of justice.

The object targeted by marriage law is essentially a specific class of social relations and social behaviors, which combine the natural and social attributes of man. "It can be said that marriage and family are the inevitable products of irreconcilability between human primitive animal nature and sociality, individual needs and social survival and development needs." Therefore, the inclusion of the duty of fidelity of husband and wife into the 
scope of the object of the legal norms of marriage and family actually reflects the jurisprudential value of marriage and family law - justice.

In addition, the establishment of the "duty of fidelity between husband and wife" in China's marriage law is also a realistic requirement of our country, and it is a realistic requirement jointly agreed upon by both parties to the marriage, which has far-reaching practical significance5.On a small level, setting the fidelity obligation of husband and wife between husband and wife and within the family is conducive to reflecting and pursuing the beautiful moral trend of love, and the harmony of husband and wife feelings and the stability of family relations are undoubtedly to create a good external and spiritual environment for the next generation, which has a positive effect on the excellent nurturing and healthy growth of the next generation; On the big level, on the one hand, the small family makes up everyone, and the security and stability of the whole society are closely related to family harmony - how many intentional injuries, homicide cases, etc. are not caused by the breakdown of the husband and wife's feelings, and the two sides fight each other? On the other hand, couples do not have to go to court frequently in order to sue for divorce, divide common property, etc., which is also a waste of judicial resources.

In short, the establishment of the fidelity obligation of husband and wife has no disadvantages, ostensibly the requirements of the present, and the value behind it is our future pursuit.

\section{References}

Chen, W. (2005). Law of Marriage and Family Succession. Beijing: Masses Publishing House, pp. 116-120.

Chen, W. (2006). COMPARATIVE Study on Foreign Marriage and Family Laws. Beijing: Masses Publishing House, pp. 176-215.

Jiang, Y. (2001). Rights and obligations of husband and wife. Beijing: law press, p. 40, p. 44, p. 70, p. 276.

Liu, Y.-L. (2011). Research on kinship Status right and Educational Economic System. Beijing: China Procuratorial Press, p. 131.

Wang, H. (2009). From Identity to Contract. Beijing: Law Press, p. 43.

\section{Copyrights}

Copyright for this article is retained by the author(s), with first publication rights granted to the journal.

This is an open-access article distributed under the terms and conditions of the Creative Commons Attribution license (http://creativecommons.org/licenses/by/4.0/). 